\title{
Biografía inédita de Francisco de Quintana: recuperación de un novelista olvidado
}

\author{
M Rocío LEPE GARCÍA \\ Universidad de Huelva \\ roclroc@hotmail.com
}

\section{RESUMEN}

Este artículo pretende desvelar datos inéditos de Francisco de Quintana, escritor del seiscientos escasamente estudiado por la crítica literaria hasta nuestros días. La investigación, a partir tanto de fuentes primarias como de su obra literaria, ha supuesto el hallazgo de información sustancial sobre este íntimo amigo de Lope de Vega. Además de aportar nuevos testimonios biográficos, esta comunicación interrelaciona acontecimientos fundamentales de su vida con su obra literaria.

Palabras clave: Biografía de Francisco de Quintana, nuevos datos de su vida y su obra, vínculos familiares, labor en la Congregación de Sacerdotes de Madrid, rectorado del hospital de la Latina, trayectoria literaria.

\begin{abstract}
This article seeks to reveal unpublished data from Francisco de Quintana, a sixteeth century author scarcely studied by literary critics to this day. The research in both primary sources and in his literary work has led to the discovery of substantial information about this intimate friend of Lope de Vega. In addition to providing new biographical evidence, this communication interrelates key events of his life with his writing.
\end{abstract}

Keywords: Francisco de Quintana's biography, new details of his life and work, family ties, his laboure in the Congregation of Priests of Madrid, rectorship at La Latina hospital, literary career.

Cuando a comienzos del año 2008 empecé a consultar la bibliografía existente sobre Francisco de Quintana y su novela la Historia de Hipólito y Aminta para emprender el proyecto de Doctorado ${ }^{1}$, me encontré con un panorama bibliográfico

\footnotetext{
${ }^{1}$ Este proyecto ha culminado en la Tesis doctoral titulada Historia de Hipólito y Aminta de Francisco de Quintana: estudio y edición crítica, defendida en la Universidad de Huelva el 7 de mayo de 2013.
} 
bastante parvo, en el que solo afloraba tímidamente alguna que otra referencia aislada sobre el autor madrileño y su segunda novela. Este primer acercamiento parecía confirmar mi impresión inicial de la escasa atención que la crítica había prestado hasta nuestros días a la vida y obra de este sacerdote madrileño aficionado desde su juventud a la literatura. La posterior profundización en los estudios de la crítica especializada sobre novela bizantina vino a refrendar esta percepción embrionaria, como dejan asimismo patente algunos de los especialistas más señeros en la novela barroca del período áureo. Como testimonios más axiomáticos podría destacar los de profesores versados en la materia, como Begoña Ripoll, Anne Cayuela, Beatriz Chenot o Antonio Cruz Casado. En el compendio de los novelistas del seiscientos titulado La novela barroca: catálogo bio-bibliográfico (1620$1700)^{2}$, Begoña Ripoll le dedica un apartado a Francisco de Quintana, del que destaca el arrinconamiento en el que la crítica contemporánea lo había mantenido hasta entonces, equiparable, por otro lado, al experimentado por el humanista Cristóbal Lozano, autor de notable éxito literario en su época y sumido también por aquel entonces en el olvido. Para la profesora Ripoll, el motivo primordial de este descuido estriba en la omisión del nombre de Quintana en los dos catálogos de novela del siglo XVII anteriores a la recopilación bio-bibliográfica, ya que tanto Carolina Bourland ${ }^{3}$ como Giovanna Formichi ${ }^{4}$ confunden al rector de la Latina con Francisco de la Cueva, autor de la Mojiganga del gusto en seis novelas ${ }^{5}$, probablemente por el seudónimo que emplea Quintana en Experiencias de amor y fortuna ${ }^{6}$, procedente del apellido de su madre, doña Clara de las Cuevas. De igual manera que la profesora Ripoll, Anne Cayuela ${ }^{7}$ y Beatriz Chenot también subrayan el menoscabo que la figura y obra literaria de Francisco de Quintana han experimentado en los estudios críticos. De manera explícita, la segunda autora manifiesta así su perspectiva del asunto: «Rares sont les histories de littérature qui

${ }^{2}$ B. Ripoll (1991).

${ }^{3}$ C. Bourland (1973).

${ }^{4}$ G. Formichi (1973), pp. 5-105.

${ }^{5}$ D. González Ramírez (2010) ha desentrañado recientemente el misterio relacionado con el escritor Francisco de la Cueva, confundido por la crítica durante bastante tiempo con nuestro autor. El patronímico Francisco de la Cueva corresponde a una invención del editor aragonés José Alfay para publicar nuevamente textos expoliados de otros autores como Lope de Vega, Antonio Liñán y Verdugo o Mateo Alemán. También el título que le otorgó a su obra Mojiganga del gusto en seis novelas es una falsificación, ya que coincide palabra por palabra con la obra de Andrés Sanz del Río (Zaragoza: Pedro Lanaja, 1641), aunque de contenido distinto. R. Bonilla Cerezo ha realizado la última edición de una de las novelas de esta obra El monstruo de Manzanares (1610). La estratagema de Alfay es uno de los numerosos casos de fraude editorial y literario del período áureo.

${ }^{6}$ F. de Quintana (1626).

${ }^{7}$ A. Cayuela (2005), p. 153. 
font mention de Francisco de Quintana, et son oeuvre n’a guère mérité l'attention des critiques» ${ }^{8}$. Del mismo modo, el doctor Antonio Cruz Casado acentúa en la edición de Los amantes peregrinos Angelia y Lucenrique ${ }^{9}$ la escasa atención que las novelas bizantinas han recibido por parte de la crítica tras la publicación póstuma de la Historia de Persiles y Sigismunda en 1617. En el listado de novelas para las que reclama una mayor atención se encuentra, entre otras, la obra cumbre de Francisco de Quintana:

Se concede escasa atención al desarrollo del género después del libro cervantino mencionado. Nos parece que no se han estudiado con el detenimiento suficiente algunas obras como la Historia de Hipólito y Aminta, Eustorgio y Clorilene, Semprilis y Genorodano, Liseno y Fenisa... ${ }^{10}$.

Sin lugar a dudas, como manifiesta el vacío crítico, la mayor parte de los expertos en literatura áurea pasa de puntillas por la semblanza y la obra de Francisco de Quintana. Algunos autores de comienzos del siglo XX le han dedicado unas palabras en sus trabajos, como queda de manifiesto en los estudios de González de Amezúa ${ }^{11}$, Joaquín del $\mathrm{Val}^{12}$ o Joaquín de Entrambasaguas ${ }^{13}$; sin embargo, las referencias resultan aisladas en las publicaciones sobre la prosa de ficción en el siglo XVII.

Habría que esperar unos años para la aparición del primer estudio monográfico sobre la producción novelística de Quintana. La tarea se le debe al lingüista esloveno Stanislav Zimic, quien publica en 1975 el artículo "Francisco de Quintana: un novelista olvidado" ${ }^{14}$. Su principal aportación consiste, más que en profundizar en las ficciones del rector de la Latina, en lograr rescatarlo del ostracismo literario al que había estado relegado hasta entonces. A partir de esta contribución y el mayor interés por el género bizantino, la atención hacia Francisco de Quintana empieza a aumentar paulatinamente en las últimas décadas del siglo XX. Tanto Antonio Cruz Casado en el estudio previo a la edición de Los amantes peregrinos Angelia y Lucenrique (1989), como Javier González Rovira en su magnífico libro La novela bizantina en la Edad de Oro ${ }^{15}$ le otorgan un capítulo completo a Quintana y su producción novelística en sendos trabajos. Y, más recientemente, el

${ }^{8}$ B. Chenot (1982), pp. 131-148.

${ }^{9}$ A. Cruz Casado (1989).

${ }^{10}$ A. Cruz Casado (1995), p. 147.

${ }^{11}$ A. González de Amezúa (1951), I, pp. 194-279.

${ }^{12}$ J. del Val (1953).

${ }^{13}$ J. Entrambasaguas (1967), p. 75 y ss.

${ }^{14}$ S. Zimic (1975), pp. 169-229.

15 J. González Rovira (1996). 
profesor italiano Andrea Bresadola ha sacado a la luz la primera edición moderna de Experiencias de amor y fortuna ${ }^{16}$, una aportación de gran valía tanto por el trabajo crítico como por el esmerado estudio introductorio.

No puede obviarse tampoco en este preámbulo la atención que algunos especialistas en novela bizantina áurea han prestado a la producción novelística de Quintana, entre ellos, el profesor Miguel Ángel Teijeiro Fuentes, quien alude en numerosas ocasiones a sus ficciones, especialmente a la Historia de Hipólito y Aminta, en sus estudios sobre el género bizantino. Sin concederle un capítulo completo en sus dos obras principales ${ }^{17}$, sus aportaciones resultan harto estimables por recuperar a Quintana del olvido atávico de la crítica, aparte de rescatar de la sombra otras novelas similares eclipsadas por la continua atención prestada a El peregrino en su patria o Los trabajos de Persiles y Sigismunda.

A estas contribuciones hay que añadir los comentarios algo más dilatados, esporádicos y a veces someros de otros críticos literarios que aparecen diseminados por distintos libros y artículos sobre novela del Siglo de Oro. Entre ellos habría que citar las observaciones de Isabel Colón Calderón en el artículo Engaños de mujeres y desengaños de los hombres ${ }^{18}$; Juan Ignacio Ferreras Tascón en La novela en España. Historia, estudios y ensayos ${ }^{19}$; Isabel Lozano-Renieblas en el artículo "Los relatos orales del Persiles"20; Pedro Ruiz en el capítulo "Entre el orden y la novedad: el cambio de siglo", en Historia de la literatura española: el siglo del arte nuevo (1598-1691) ${ }^{21}$; o Víctor Infantes en Del libro áureo ${ }^{22}$ y Carlos García Gual en "Menéndez Pelayo y sus estudios sobre las novelas griegas y latinas, antes y en sus orígenes de la novela" ${ }^{\text {. }}$. Grosso modo, este es el sucinto panorama crítico existente sobre Francisco de Quintana y su obra al comienzo de la investigación doctoral $^{24}$.

Para ahondar en la biografía del autor madrileño, prioricé entre otras cuestiones la fecha de su nacimiento, establecida hasta entonces de manera imprecisa; la formación académica, sin verificar con datos documentales; el curso de su carrera eclesiástica, carente de cualquier información, incluso de fecha de ordenación sacerdotal; las ocupaciones desempeñadas en la Congregación de San Pedro o el

\footnotetext{
${ }^{16}$ F. de Quintana (2012).

${ }^{17}$ M. Á. Teijeiro Fuentes (1988). Y M. Á. Teijeiro Fuentes y J. Guijarro Ceballos (2007).

${ }^{18}$ I. Colón Calderón (1989), pp. 111-124.

19 J. I. Ferreras Tascón (2009), II.

${ }^{20}$ I. Lozano-Renieblas (2002), pp. 111-126.

${ }^{21}$ P. Ruiz Pérez (2010), III.

${ }^{22}$ V. Infantes (2006).

${ }^{23}$ C. García Gual (2007).

${ }^{24}$ En el primer acercamiento, compilé toda la información existente sobre Quintana en sus obras, autores contemporáneos, biógrafos y bibliófilos, prólogos y referencias tanto de la crítica actual como de los estudios generales sobre novela del siglo XVII.
} 
proceso de sucesión en la regencia del Hospital de la Latina. El rastreo de estos datos implicaba a su vez la complementación de otros vacíos biográficos, tales como el acercamiento a su familia, la relación con su tío don Jerónimo de Quintana o el seguimiento de los pleitos resultantes de su condición de sobrino legatario.

\section{Los primeros años}

Para componer esta biografía, he investigado en las tres fuentes documentales más fidedignas, probablemente no consultadas antes por parte de la crítica, como son las Actas de la Venerable Congregación de San Pedro de Sacerdotes Naturales de Madrid $^{25}$, de la que fue hermano Francisco de Quintana desde el 13 de mayo de 1625; los libros del Archivo Histórico Nacional, donde se encuentra toda la documentación de la Universidad de Alcalá de Henares anterior a 1977; y los legajos del Archivo Histórico Diocesano de Toledo ${ }^{26}$. Todos estos documentos, aparte de aportar información nueva y relevante sobre el rector de la Latina, han puesto en cuestión algunas de las premisas aceptadas por la crítica especializada hasta nuestros días.

Siguiendo un orden cronológico, la investigación en las fuentes primarias ha permitido en primer lugar la datación de la fecha de nacimiento y bautizo de Francisco de Quintana. La primera estaba establecida en los libros de referencia de manera aproximativa en las postrimerías del siglo XVI, en torno al año $1595^{27}$, o en el "alba del siglo" ${ }^{28}$. Su conocimiento ha venido dado por la aparición, entre los innumerables legajos del Archivo eclesiástico de Toledo, de un documento clave: el acta notarial de la partida de bautismo de Quintana expedida para las ordenaciones a epístola y evangelio ${ }^{29}$. Este manuscrito, trascendental para las pesquisas, aportaba dos datos desconocidos hasta el momento: la fecha de su nacimiento, el día 7 de marzo de 1599, y la de su bautismo, celebrado solo diez días después, el 17 de marzo. El documento está certificado por don Bernabé Montero, notario apostólico de la audiencia arzobispal de Madrid. Transcribo textualmente la partida, que está

\footnotetext{
${ }^{25}$ Gracias a la generosa colaboración del padre don Enrique Contreras Abad, pude acceder a los libros de actas de la Congregación. B. Chenot cree que estos documentos desaparecieron "a la suite des incendies qui ont dévasté les archives de la Congregation en 1936, ces livres ont disparu” (1982), p. 131. No obstante, la Congregación conserva aún una decena de libros de actas desde su fundación. En los tres primeros aparecen datos de gran valor sobre nuestro autor: Libro de elecciones de oficiales y acuerdos de la Congregación (25 de junio de 1619 a 11 de agosto de 1625), Libro II de Acuerdos (22 de agosto de 1624 a 3 de mayo de 1646) y Libro III de Acuerdos (2 de julio de 1646 a 17 de abril de 1662).

${ }^{26}$ Estas aportaciones las incluyo en mi tesis doctoral, M. R. Lepe (2013), pp. 13-51.

${ }^{27}$ Hacia esta datación se inclinan B. Ripoll (1991) y el ABEPI (1986), I, pp. 361-364.

${ }^{28}$ E. González Mas (1989), III, p. 405.

${ }^{29}$ Esta partida se solicitaba normalmente para la ordenación de corona; sin embargo, podía requerirse de manera extraordinaria posteriormente por otros motivos.
} 
tomada del folio 51 a la segunda plana del Libro de partidas de bautismo de la iglesia de los Santos Justo y Pastor de Madrid donde fue bautizado Francisco de Quintana:

En diecisiete días del mes de marzo de 1599 años, yo el licenciado Francisco de las Cuevas, de consentimiento del licenciado Sebastián de Mesa, cura propio desta iglesia de San Justo y Pastor desta villa de Madrid, bauticé a Francisco, hijo de Francisco de Quintana, curtidor, y de Clara de las Cuevas, su mujer, naturales desta dicha villa, que viven en la calle de Mira el Río. En casas suyas propias nació el niño a siete deste dicho mes y año. Fueron padrinos Nicolás de Escobar y María de Escobar, y testigos Blas de Quintana y Cristóbal de Quintana y Martín Nieto y otros, y lo firmó el licenciado Cuevas, la cual dicha partida va cierta y verdadera y concuerda con la original del libro que debía entregar al dicho licenciado Martín Guajardo ${ }^{30}$.

Además de esta información inédita, el acta notarial aporta otros datos de interés sobre la familia de Quintana, algunos de ellos ya expuestos por Joaquín de Entrambasaguas $^{31}$. Entre esta información subsidiaria se hallan los nombres de sus progenitores, don Francisco de Quintana y doña Clara de las Cuevas; el lugar de residencia de la familia, la calle de Mira el Río ubicada cerca del Palacio Real; y la parroquia donde recibió el sacramento bautismal, la iglesia de los Santos Justo y Pastor. El documento alega asimismo otros detalles nuevos como la profesión del padre, curtidor de oficio; los nombres de los padrinos del recién nacido, Nicolás de Escobar y María de Escobar, y de los testigos del oficio, Blas de Quintana y Cristóbal de Quintana; y, finalmente, el nombre del sacerdote que celebró el sacramento con licencia del párroco.

A esta información inédita, Joaquín de Entrambasaguas añade otros datos sobre la familia del Quintana ${ }^{32}$, como son los nombres de sus abuelos paternos, don Juan de Quintana y doña María de Durruza, naturales de Madrid, y maternos, don Miguel de las Cuevas y doña Ana de Aranda, oriundos de Soria y Toledo, respectivamente; el número de hijos del matrimonio, tres varones contando a nuestro autor; los nombres de sus hermanos, Blas y Antonio, así como los empleos de estos: el primero, fraile franciscano, y el segundo, curtidor como su padre. Siguiendo la tradición familiar, este último ingresó en la Orden Tercera franciscana el 23 de agosto de 1644. Entrambasaguas informa asimismo de las segundas nupcias de don

${ }^{30}$ El documento apareció sin fecha entre los legajos del Archivo de Toledo.

${ }^{31}$ J. de Entrambasaguas (1967), pp. 75 y ss. Es bastante probable que este crítico accediera a la fuente referida, ya que es el único documento donde he encontrado información directa sobre su familia.

${ }^{32}$ Ibíd. 
Francisco de Quintana padre con Ana de Barrientos tras la muerte de su primera esposa, de cuyo enlace nació al menos una hija llamada Ana de Quintana. Su acta de ingreso en la Orden Tercera de San Francisco, el día 10 de marzo de 1648, expone que en esa fecha "estaba soltera y vivía a las Tabernillas, a espaldas de Castillo, panadero de Corte, feligresía de San Andrés”. La siguiente cláusula de don Jerónimo de Quintana en su testamento podría apuntar a la existencia de más hermanas: "Mando al doctor Francisco de Quintana mi primo, doscientos ducados para ayuda al remedio de sus hermanas y una docena de cuerpos de libros de Teología escolástica o positiva, los que escogiere...”33 Pero es probable que con el término "hermanas" don Jerónimo se refiera a las religiosas de la Concepción franciscana, cuyo convento se encontraba aledaño al hospital de la Latina. La materia religiosa de los libros refrenda esta teoría, pero no es concluyente.

Pocos datos más se pueden aportar sobre el entorno familiar de Quintana y sus primeros años de vida. Begoña Ripoll sostiene que el futuro clérigo pasó su infancia y juventud bajo la protección de su tío don Jerónimo de Quintana ${ }^{34}$; sin embargo, las palabras de Juan Pérez de Montalbán en la dedicatoria a su amigo en Los primos amantes, séptima novela de Sucesos y prodigios de amor, apuntan más bien a un fuerte vínculo afectivo con sus progenitores, quienes aún vivían en 1627: «Viene a ser interés mío que se conozca el afecto que a V.M. y a sus padres he tenido siempre» ${ }^{35}$. La optación final de la dedicatoria podría confirmar esta teoría: "Y dele Dios la vida que deseo en compañía de sus padres”36. Sin embargo, este lazo familiar no es óbice para que don Jerónimo de Quintana desempeñara un papel relevante en la vida de su sobrino. Seguramente fue su mentor y el principal forjador de su carrera eclesiástica. Asimismo, la sucesión de su sobrino en el cargo de rector en el hospital de la Latina y el nombramiento como albacea en su testamento corroboran la inclinación afectiva de don Jerónimo hacia su allegado.

Otra cuestión relacionada con este asunto concierne al grado de parentesco entre los dos sacerdotes. La crítica no parece ponerse de acuerdo al respecto: unos emplean el binomio tío y sobrino y otros, el término primos. La mayor parte se decanta por la primera filiación; sin embargo, las palabras de don Jerónimo, denominando "primo» a su pariente en un par de ocasiones en el testamento, han inclinado a algunos críticos a catalogar la relación familiar como tal. Recojo a continuación una de las referencias de sus últimas voluntades:

Y para cumplir y pagar este mi testamento y lo en él contenido, dejo y nombro por mis albaceas y testamentarios a los señores D. Juan de Lira

\footnotetext{
33 A. Matilla Tascón (1983), p. 197.

${ }^{34}$ B. Ripoll (1991), p. 131.

35 J. Pérez de Montalbán (1999), p. 231.

${ }^{36}$ Ibíd., p. 232. El óbito de la madre de Quintana debió de ser por tanto posterior a esta fecha.
} 
[...]y a Manuel Vega, escribano del número de esta villa de Madrid y al doctor Francisco de Quintana, rector del Hospital de la Latina, mi primo... ${ }^{37}$

Sin embargo, ambos parentescos pueden considerarse adecuados como se verá a continuación. Las claves de la consanguinidad quedan de manifiesto igualmente en el testamento de don Jerónimo, donde se aportan algunos datos relevantes para desentrañar esta cuestión. Su padre, don Francisco de Quintana, escribano del rey, rector y mayordomo del hospital de la Latina, era hermano de don Juan de Quintana, abuelo del novelista. Por lo que de acuerdo con estos vínculos, don Jerónimo y don Francisco de Quintana padre eran primos hermanos y, consiguientemente, los dos escritores primos o tío y sobrino. Para ver con mayor claridad el entronque familiar, esbozo a continuación el árbol genealógico de la rama paterna.
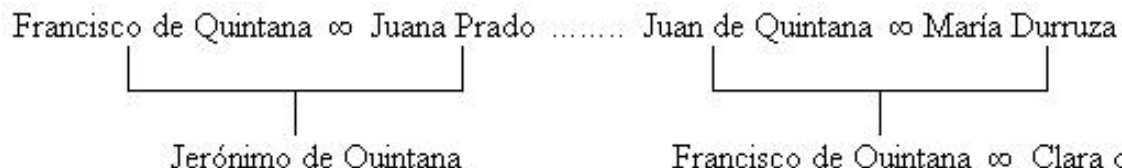

Francisco de Quintana $\infty$ Clara de las Cuevas

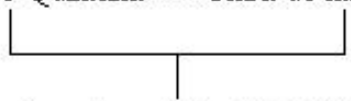

Francisco / Blas / Cristóbal

Siguiendo con otro asunto importante, la educación y los estudios de Quintana, hasta el momento presente no existe ninguna noticia de ningún tipo sobre el proceso de aprendizaje de las primeras letras. Cualquier anotación o comentario sobre esta materia, supondría irrumpir en el ámbito de la conjetura, aunque no sería desacertado apuntar a que esa instrucción se debió de desarrollar en un marco religioso notable. De lo que sí existe ya completa certeza es de su formación posterior. Sus biógrafos, antes de iniciar esta investigación, admitían la realización de la carrera eclesiástica, la licenciatura en Filosofía y Teología y, posteriormente, el doctorado en la segunda disciplina ${ }^{38}$. En el estadio previo a la búsqueda de información, la crítica se decantaba por la realización de los estudios en la Universidad de Alcalá de Henares, pero en ningún trabajo se acreditaba el paso por

\footnotetext{
${ }^{37}$ J. Matilla Tascón (1983), p. 199.
}

${ }^{38}$ Se le denomina Licenciado en el poema "Fénix y cisne os contemplo", en la dedicatoria de Sucesos y prodigios de amor y en la portada de Experiencias de amor y fortuna. El título de Doctor, por su parte, aparece en el Para todos, en los preliminares de Tiempo de regocijo, en la portada de Hipólito y Aminta y en los libros de actas de la Congregación de San Pedro. Concretamente, el primer testimonio de este título aparece en el acta de ingreso en la Congregación de Sacerdotes Naturales de Madrid. 
los colegios complutenses con documentos académicos ${ }^{39}$. Para verificar este dato con total certeza, el único camino válido suponía el acercamiento a las fuentes documentales: los libros de matrículas, las pruebas de acceso y las certificaciones de esta institución universitaria. En ellos, concretamente en los libros de matrículas del Colegio de San Ildefonso, encontré los documentos que necesitaba para confirmar esta teoría consuetudinaria. Con los datos encontrados hoy por hoy se puede revalidar que Quintana estudió teología en la Universidad de Alcalá de Henares entre los años 1616 y $1622^{40}$, donde coincidió con sus íntimos amigos Lope de Vega ${ }^{41}$ y Pérez de Montalbán ${ }^{42}$. El afecto mutuo de los tres escritores queda de manifiesto en los poemas, las dedicatorias y los elogios que se prodigan en sus obras. Esta documentación descarta irrefutablemente la teoría de que pudiera estudiar en la Universidad de Salamanca, a pesar de las digresiones ponderativas dedicadas a esta institución universitaria en sus dos novelas.

Su carrera eclesiástica se desarrolla de manera paralela a estos estudios universitarios. Según sus coetáneos, Quintana fue un gran teólogo y uno de los mejores predicadores de su tiempo. Con el fin de sondear su itinerario formativo acudí también al Archivo Histórico Diocesano de Toledo donde se atesoran desde el siglo XVI abundantes documentos y manuscritos eclesiales. Entre los legajos conservados en los anaqueles del archivo, encontré los pliegos que bosquejan la preparación eclesiástica de Francisco de Quintana, la cual culminó el día 29 de septiembre de 1624 con la celebración de su ordenación sacerdotal, unos meses antes del ingreso del autor en la Congregación de San Pedro. El acto, que mandó a celebrar su Alteza el Cardenal Infante don Fernando, estuvo presidido por don Melchor de Soria y Vera, obispo de Troya y auxiliar de Toledo ${ }^{43}$. En él participaron trescientos ochenta y nueve ordenantes que previamente habían sido examinados por el señor don García de Paredes, canónigo de la Santa Iglesia de Toledo y examinador general del arzobispado de dicha ciudad.

Un año antes de este acontecimiento, el joven ordenante recibió, gracias a una solicitud de dispensa de las témporas, los grados de epístola (subdiaconato) y evangelio (diaconato). El día 4 de septiembre de 1623, el arzobispo de Toledo, el Cardenal Infante don Fernando, envió por medio de don Manuel Perpetuo, misado

${ }^{39}$ S. Zimic apunta a que Quintana pudo estudiar en una de las dos Universidades, pero no se decanta por ninguna de ellas ante la falta de acreditación documental (1975), p. 172.

${ }^{40}$ Libros de matrículas de la Universidad de Alcalá, libros 444 y 445.

${ }^{41}$ El nombre de Lope aparece de manera continuada en los registros de la Universidad Complutense desde el año 1612. Aparece matriculado en Teología en 1612 y 1615 y en Teología y Cánones en 1613, 1614, 1616 y 1617. En 1618 aprobó cuatro cursos de Teología escolástica y en 1619 estuvo matriculado de nuevo en Cánones y Teología (Libro 487, fol. 26 de pruebas de curso).

${ }^{42}$ Montalbán obtuvo el grado de bachiller en 1620 y luego se doctoró en Alcalá de Henares.

${ }^{43}$ El cargo correspondía en esa fecha a don Melchor de Soria y Vera, natural de Jaén. 
de Toledo, una carta al párroco de la iglesia de los Santos Justo y Pastor, don Martín Guajardo, para que notificara públicamente en la iglesia las amonestaciones de la ordenación de evangelio por "si hubiere o se opusiere algún impedimento". La carta dictaba que el aviso se notificara "un día de domingo o fiesta de guardar" cuando más público se "ayuntara" en la iglesia. En ella se solicitaba asimismo que se fecharan las diligencias en un sobre cerrado con información de la vida y costumbres del aspirante, al que había de adjuntarse una certificación que diera constancia de haber ejercido la función de subdiácono al menos en seis ocasiones.

Dos semanas más tarde, el 16 de septiembre del mismo año, don Martín Guajardo contestaba a la carta anterior certificando que la solicitud se cumplió el día 8 de septiembre en la misa mayor "al tiempo del ofertorio como es uso y costumbre” y no se encontró impedimento alguno para la ordenación de evangelio. Certificaba también que Francisco de Quintana había cumplido el requisito de cantar más de seis veces en misa y era "una persona virtuosa, de buena vida y costumbres, hábil y suficiente para el dicho ministerio”. Cinco días más tarde, Francisco de Quintana presentó ante el Cardenal Infante una publicación y diligencia necesarias para la ordenación de evangelio. En el mismo documento, fechado el día 21 de septiembre de 1623, se recoge la certificación para la ordenación de diácono. La publicación para el evangelio, hecha en virtud de los señores del consejo de su alteza, fue firmada por Bernabé Montero, notario apostólico de la audiencia arzobispal de Madrid.

Entre los escasos legajos sueltos almacenados en el archivo diocesano sobre el expediente de Quintana, localicé también otro manuscrito firmado un año antes, el día 14 de septiembre de 1622, por el mismo escribano don Bernabé Montero, donde el ministro daba fe de haber visto en presencia de Martín Guajardo y Pedro de Aybares un documento relativo al joven asistente, pero cuyo carácter no se detalla en el escrito. Por la participación del sacerdote de la iglesia de los Santos Justo y Pastor como testigo podría tratarse de una nueva partida de bautismo, la cual era habitualmente requerida para recibir las órdenes menores, sobre todo en los casos de ordenación de corona. Este documento induce a creer que su primera ordenación eclesiástica se celebró en el año 1622, aunque por el vacío de documentos acreditativos no resulta posible confirmarlo taxativamente.

Francisco de Quintana fue célebre entre sus contemporáneos, aparte de por la faceta de escritor, por sus méritos como teólogo y predicador, cualidades que rememoran notablemente sus biógrafos posteriores. Su amigo Juan Pérez de Montalbán, quizá el más ferviente de los adalides, distingue a Quintana, pues, en el Índice de los ingenios de Madrid, contenido en el Para todos (1632), como "excelentísimo poeta, filósofo y teólogo" y pondera sus trabajos calificándolos "de gran peso, como puede seguramente creerse de su mucha erudición y continuos 
estudios”44. Su erudición y conocimientos quedan destacados igualmente en la aprobación de la Historia de Hipólito y Aminta donde emplea los siguientes términos encomiadores: "Hallarán en él los filósofos doctrina, y los políticos preceptos, los cortesanos avisos..."45

De su fama como predicador queda constancia asimismo en varios documentos de la época, tales como la aprobación rubricada por fray Diego Niseno en el sermón fúnebre que compuso Quintana para las honras fúnebres de Lope de Vega:

Es tan cabal, tan perfecto el panegírico, que había de quedar para modelo y ejemplar de funerales oraciones, pues aquí se halla el lenguaje sin afectación, la escritura con agudeza y la verdad sin sospecha. Todo lo cual pretenden muchos en semejantes acciones y consiguen pocos con la felicidad y acierto que el doctor Quintana, que a las esclarecidas luces del inimitable varón que aplaude, ha ganado en sus honras la mayor que jamás se podrá solicitar ${ }^{46}$.

La también aprobación firmada por Juan Bautista Dávila de la Oración panegírica escrita para su entrañable amigo Juan Pérez de Montalbán: "He visto en esta Oración Panegírica del Doctor Francisco de Quintana a un escriturario con aseo, un predicador con firmeza, y un panegirista con juicio"47. Y un acta de la Congregación de San Pedro fechado en 1634, en el que el secretario en funciones, José de las Cuevas, elogia el discurso pronunciado por Quintana para defender su candidatura a capellán mayor de la Comunidad: "Predicó el señor doctor Francisco de Quintana congregante nuestro con gran erudición y admiración desta insigne congregación a que fui presente".

Estas cualidades también son subrayadas por biógrafos y bibliófilos coetáneos y posteriores. Nicolás Antonio en Bibliotheca hispana nova realza de Quintana que estaba "philosophicis atque theologicis imbutus disciplinis"48. Y Álvarez de Baena en Hijos de Madrid, remitiéndose a fuentes anteriores, constata su celebridad considerándolo un "Teólogo, Filósofo y Predicador de los más célebres de su tiempo" ${ }^{49}$.

Sin embargo, los testimonios más conspicuos de su formación como teólogo y predicador proceden de los sermones escritos para las homilías, dos fúnebres para

\footnotetext{
44 J. Pérez de Montalbán, Para todos (1999), p. 859.

${ }^{45}$ F. de Quintana (1627), fol. 2v., preliminares, aprobación de J. Pérez de Montalbán.

${ }^{46}$ F. de Quintana (1635), preliminares, aprobación de fray Diego Niseno, sin foliar.

47 Aprobación de J. Bautista Dávila (1639?). Esta oración se encuentra en Lágrimas panegíricas, de Pedro Grande de Tena, Imprenta del reino, 1639?, y en un volumen aparte con otras obras.

${ }^{48}$ N. Antonio (1996), p. 463. La obra fue publicada póstumamente en 1696.

${ }^{49}$ J. A. Álvarez de Baena (1789-90), II, pp. 172-173.
} 
las exequias de Lope de Vega y Pérez de Montalbán y una predicación de cuaresma, Del premio eterno de los justos (1645) incluida en una colección de sermones varios $^{50}$. Los tres discursos muestran al Quintana más erudito de toda su obra. Aparte de la disertación teológica y la abundancia de lugares comunes literarios, el discurso descuella por una extraordinaria profusión estilística, consistente primordialmente en el empleo de recursos de amplificatio y la predilección por los juegos contrastivos ${ }^{51}$.

\section{Vida sacerdotal}

Otro hito especialmente señero en la biografía de Quintana reside en su ingreso y dilatada trayectoria en la Venerable Congregación de Sacerdotes Naturales de Madrid. Aunque Entrambasaguas ya había revelado algunos datos sobre el paso de Quintana por la Hermandad, resultaba conveniente consultar las fuentes primarias para completar su itinerario en la Comunidad. Gracias a las indagaciones en los libros de Actas custodiados en la Mutual del Clero en Madrid puede confirmarse que el ingreso de Francisco de Quintana en la Venerable Congregación de San Pedro tuvo lugar el día 13 de mayo de 1625 en la iglesia parroquial de San Miguel de los Octoes en Madrid. El acto se celebró ante la presencia del capellán mayor de la Comunidad en esa fecha, el licenciado Eugenio de Bustamante, tal como el secretario Francisco Pérez recoge en acta. El Libro I de Acuerdos de la Congregación contiene la siguiente descripción de la ceremonia:

Primeramente, habiéndose leído siete memoriales de los Señores Licenciados, contando ser naturales por los títulos (de que doy fe yo el infrascrito de haberlos visto) y habiendo jurado la Limpia Concepción de Nuestra Señora, y de guardar las Constituciones de la Congregación y de decir dos misas cada mes para los gastos de ella, se los admitió y recibió por hermanos congregantes ${ }^{52}$.

En esta misma celebración ingresa en la Comunidad de San Pedro Juan Pérez de Montalbán, compañero e íntimo amigo de Quintana. Y solo un mes más tarde, el 29 de junio de 1625, el maestro Lope de Vega.

\footnotetext{
${ }^{50}$ Se encuentra en Escuela de discursos formada de sermones varios (1645).

${ }^{51}$ Para la faceta de Quintana como predicador, véanse S. Zimic (1975), pp. 182-188; F. González Olmedo (1935), pp. 416-418; E. Di Pastena (2001) y, más recientemente, el artículo de A. Bresadola (2012). Este último realiza un estudio minucioso sobre los dos sermones escritos por Quintana para celebrar las honras fúnebres de sus amigos. En el análisis comparativo, el profesor Bresadola atiende a cuestiones muy diversas: pragmáticas, temáticas, estructurales y estilísticas.

${ }^{51}$ Se encuentra en Escuela de discursos formada de sermones varios (1645).

${ }^{52}$ Libro I de Acuerdos, fol. 119.
} 
Quintana desempeñó en la Compañía desde su anexión inaugural actividades muy diversas y ocupó puestos bastante destacados. En los libros de Actas de la Congregación están documentadas las distintas funciones que desempeñó el novelista a lo largo de su vida, algunas de ellas ejercidas incluso en repetidas ocasiones, tales como los cargos de tesorero, ropero, contador, comisario de cárcel, consiliario y el puesto más honorífico de capellán mayor desempeñado en tres períodos (1634, 1643 y 1649).

El ingreso de Quintana en esta Comunidad respondía a unos vínculos familiares y afectivos muy definidos. La Congregación de Sacerdotes fue fundada en el año 1619 por su tío don Jerónimo de Quintana. El hospital de la Concepción de Nuestra Señora, conocido con el nombre del Hospital de la Latina, estaba ubicado en la calle de Toledo, anexo al convento de la Concepción franciscana. Con fines caritativos atendía a los enfermos pobres y necesitados, y entre ellos a los sacerdotes menesterosos de Madrid que vivían de manera indecorosa. Esta pobreza del bajo clero impulsó a don Jerónimo a fundar la Congregación de Sacerdotes con el fin de velar por los clérigos indigentes y presos de la ciudad. Los objetivos de la Hermandad aparecen recogidos en el Libro de elecciones de oficiales y acuerdos de la Congregación ("Licitud con los presos de la cárcel, entierros de pobres y otras limosnas”,53), unas intenciones que su sobrino recuerda en Las honras a Lope de Vega al mencionar las virtudes caritativas del fallecido: "Ocupase esta Congregación Venerable en socorrer a los sacerdotes pobres, negociar su libertad a los presos y enterrar a los difuntos ${ }^{\text {54 }}$. Tras su constitución, la junta de la Comunidad se reunió por primera vez el día 25 de junio de 1619 en una capilla del hospital de la Latina para establecer los oficios. La aprobación y licencia de la Congregación corrieron a cargo del ordinario diocesano, por entonces el cardenal infante don Fernando. En esta primera junta don Jerónimo de Quintana fue nombrado capellán mayor, un privilegio que volvería a ostentar de nuevo años más tarde en $1639^{55}$.

Igual que su tío, Francisco de Quintana también ejerció el cargo distintivo de capellán mayor de la Congregación, en su caso en varios momentos. Es presumible que la primera elección al puesto en el año 1634 estuviera cargada de polémica debido a la aspiración al puesto de tío y sobrino, tal como queda recogido en acta en

\footnotetext{
${ }^{53}$ En el acta del día 16 de agosto de 1619 se fija asimismo el dinero que la Comunidad va a destinar a la soltura de los sacerdotes presos, una cantidad de 16 reales.

${ }^{54}$ F. de Quintana (1635), fol. 10.

${ }^{55}$ Don Jerónimo de Quintana desempeñó en la congregación diversidad de funciones igual que su sobrino. Además de estas actividades fue un celebrado cronista de la ciudad de Madrid. Por sus actividades literarias y humanitarias, Lope lo alaba en la silva VII del Laurel de Apolo: "Y a Jerónimo, ilustre de Quintana, / A cuyas letras y virtud iguales. / Debe la patria elogios inmortales”.
} 
el Libro II de acuerdos de la Congregación ${ }^{56}$. La votación, que concluyó con un resultado de veintitrés votos para Francisco de Quintana y trece para don Jerónimo, acabó otorgando la distinción al sobrino. Este puesto lo desempeñó en otras dos ocasiones, como indican Álvarez de Baena ("siendo tres veces su capellán mayor”,57), Joaquín de Entrambasaguas ${ }^{58}$ y certifican los Libros de Acuerdos de la Congregación de 1643 y 1649 respectivamente ${ }^{59}$, aunque en el certificado de fallecimiento del autor solo se hace mención al primer nombramiento "fue su capellán mayor el año de 1634”. Quintana se entregó al servicio de la Congregación en cuerpo y alma, como corrobora igualmente Álvarez de Baena, quien considera que la sirvió "con especial esmero en muchos empleos". Menciono a continuación la relación de sus funciones en la Hermandad a partir de la información extraída de los Libros de Actas de la Comunidad: diputado de cárcel (1627), cerero (1628), secretario (1629), contador (1630), comisario de cárcel (1631), capellán mayor $(1634)^{60}$, comisario de cárcel (1635), diputado en colaboración con su tío para "pedir la soltura de los pobres sacerdotes de la cárcel de la corona" (1636) ${ }^{61}$, consiliario (1639) ${ }^{62}$, capellán mayor (1643) ${ }^{63}$, consiliario (1644), diputado de cárcel (1645), ropero y comisionado para examinar con otros miembros de la Congregación sus constituciones $(1647)^{64}$, comisario de cárcel $(1648)^{65}$, capellán mayor (1649), consiliario (1650) y ropero (1654).

Otro acontecimiento especialmente significativo en la biografía del autor resulta su distinción honorífica como rector del Hospital de la Latina. El maduro sacerdote sucede a su tío en las funciones de superior de la institución, pero al comienzo de la investigación quedan incógnitas por resolver, tales como el momento y las circunstancias del relevo. Existen datos palmarios en torno al fallecimiento de don Jerónimo de Quintana: su óbito se produjo el 8 de noviembre de 1644 y el entierro se ofició al día siguiente por la mañana en la iglesia de las religiosas de la Concepción franciscana, atendiendo a las últimas voluntades de su testamento. A tenor de las palabras de Álvarez de Baena, las honras fúnebres fueron solemnes y asistieron a ellas todos los miembros de la Congregación de San Pedro y las religiosas de las Descalzas Reales. La ceremonia fue oficiada por don Bernabé Perea, capellán mayor de la Congregación en esa fecha, y la predicación

${ }^{56}$ Libro II de Acuerdos, 3 de julio de 1634, fols. 115 y ss.

${ }^{57}$ J. A. Álvarez de Baena (1789-1790), II, p. 172.

58 J. de Entrambasaguas (1967), p. 75.

${ }^{59}$ Libro III de Acuerdos, actas de 6 de julio de 1643 y 3 de julio de 1649.

${ }^{60}$ La elección tuvo lugar el día 3 de julio de 1634, Libro II de Acuerdos, fols. 114 v y ss.

${ }^{61}$ Libro II de Acuerdos, 5 de mayo de 1636.

${ }^{62}$ Ibíd., junta celebrada el día 8 de agosto del 1639.

${ }^{63}$ El cargo es designado en junta celebrada el día 6 de julio de 1643.

${ }^{64}$ Libro III de Acuerdos, 10 de julio 1647, fols. 9-10.

${ }^{65}$ Ibíd., 13 de julio de 1648, fol. 21. 
correspondió al doctor Felipe de Godínez. Los dos enigmas que derivan de este suceso atañen a cuándo y cómo se llevó a cabo la sucesión, si el nombramiento se produjo tras la defunción o fue anterior. Y, en el segundo caso, cuáles fueron sus particularidades.

Una parte importante de la crítica se inclina a retrasar la transferencia de funciones al año 1644, tras el fallecimiento de don Jerónimo ${ }^{66}$. Otra, sin embargo, anticipa el acontecimiento a fechas anteriores al deceso. Joaquín de Entrambasaguas, por ejemplo, adelanta el relevo al año $1641^{67}$, una datación bastante posible atendiendo a que Francisco de Quintana firma la aprobación de la Garduña de Sevilla ese mismo año con la distinción de "rector del hospital de la Latina"68. Mi hipótesis, algo más arriesgada, pero igualmente fundada en referencias literarias, presume la antelación de la toma de funciones al año 1639, ya que en la portada de la Oración panegírica a Pérez de Montalbán, publicada en Lágrimas panegíricas previsiblemente ese mismo año, aparece la siguiente mención: "Cuidado afectuoso de su íntimo amigo, el Doctor Francisco de Quintana, Rector del Hospital de la Concepción, vulgarmente la Latina"69. Puede ser que la datación de Lágrimas panegíricas responda a una confusión tipográfica, una circunstancia un tanto improbable; también que la obra se publicara más tarde, dada la imprecisión de la fecha, o que efectivamente Francisco de Quintana ocupara ya el cargo de rector en funciones en 1639 supliendo a su tío por algún motivo concreto, como pudiera ser que el anciano cronista estuviera aquejado de algún problema de salud. En cualquier caso, lo cierto es que Francisco de Quintana sucedió a su tío en el rectorado del hospital antes de su fallecimiento y que el cargo de rector lo desempeñaba al menos desde el año 1641, aunque me atrevo a afirmar que pudo ejercerlo incluso con anterioridad.

La muerte de don Jerónimo de Quintana entrañó, aparte de incontables responsabilidades, ciertos reveses inesperados en la vida de su sobrino. Como albacea del testamento ${ }^{70}$, Francisco de Quintana se vio obligado a hacer frente a las diversas disposiciones del testador. En sus últimas voluntades, fechadas solo un año

${ }^{66}$ La sucesión en el puesto se produjo para algunos autores, como J. A. Álvarez de Baena (1789-1790), II, p. 173; B. Ripoll (1991), p. 131; B. Chenot (1982), p. 131, y J. del Val, (1953), III, p. LXXIII, tras la muerte de don Jerónimo de Quintana. No obstante, unas páginas después, B. Chenot (1982, p. 134) afirma que la vida literaria de Quintana transcurrió entre 1622 y 1639, debido a que las posteriores obligaciones en el cargo de rector del hospital le impidieron su dedicación a la literatura.

67 J. de Entrambasaguas (1967), p. 75.

${ }^{68}$ A. de Castillo Solórzano (1642).

${ }^{69}$ S. Zimic lo aprecia al indicar que “en 1638, aquel ya reclama este título” (1975), p. 188.

${ }^{70}$ Junto a los señores don Juan de Lira, caballero de la Orden de Santiago, y don Manuel de Vega, escribano del número de la villa de Madrid, A. Matilla Tascón (1983), p. 199. 
antes de la defunción, el 13 de noviembre de 1643, don Jerónimo solicita lo siguiente a su deudo:

Por ser yo uno de los primeros fundadores de la Congregación [...], y ella tiene por estatuto de hacer cada año la fiesta de la Purísima Concepción de la Virgen María nuestra Señora, de cuya prerrogativa y festividad yo soy aunque tan tibio, muy devoto, y para que con mayor asistencia de la Congregación, solemnidad y autoridad se haga, mando a la dicha Congregación un censo que tengo contra las personas y bienes de Juan Baptista Román, tratante en tocino, vecino de esta dicha villa, de mil y cuatrocientos ducados de plata de renta en cada uno un año, para que la dicha renta se distribuya entre los congregantes que se hallaren presentes a ella $[\ldots]^{71}$

El cumplimiento de esta cláusula originó pleitos y contratiempos que dificultaron bastante la vida de su sobrino. Álvarez de Baena hace mención a los litigios resultantes de esta designación fiduciaria y al socorro que la Comunidad le prestó en varias ocasiones para reparar su situación de pobreza y necesidad ${ }^{72}$. En esta primera referencia al asunto no se especifica el motivo de los pleitos. Beatriz Chenot, más recientemente, ha apuntado como causa de esta miseria los problemas financieros ocasionados por la sucesión de su tío: “Cette charge l'amena à s'occuper des problèmes financiers soulevés par cette succession; et les querelles de procedure qui s'ensuivirent le réduisirent à la misère"73.

No obstante, tanto la cláusula del testamento como las referencias de los libros de actas de la Congregación parecen apuntar en otra dirección. Como estipula el documento, a Quintana le corresponde, en cumplimiento de la voluntad de su tío, entregar anualmente a la Congregación de Sacerdotes de Madrid las rentas del censo estipuladas en la disposición. Las dificultades en la obtención del dinero por una parte o bien en el proceso de transmisión del censo a la Comunidad debieron de ocasionar los pleitos con los mismos hermanos de la Comunidad. En los Libros de Acuerdos de la Congregación se pueden espigar algunas referencias relacionadas con el asunto. Por razones de espacio solo selecciono algunas de ellas:

Se da poder a tres congregantes para que prosigan el pleito que la Congregación hace con el Dr. D. Francisco de Quintana, nuestro hermano, sobre que examine el censo que el ldo. Jerónimo de Quintana mandó a la Congregación, cuya renta se ha de distribuir el día de la Concepción ${ }^{74}$.

${ }^{71}$ Ibíd., p. 196.

72 J. A. Álvarez de Baena (1789-1790), II, p. 173.

${ }^{73}$ B. Chenot (1982), pp. 131-132.

${ }^{74}$ Libro II de Acuerdos, 18 de agosto de 1645, fol. 229. 
El licenciado D. Sebastián Muñiz suspende las diligencias de este pleito por ahora y con los dichos réditos se cumpla la distribución conforme a la cláusula del testamento del ldo. Jerónimo de Quintana, que esté en gloria $^{75}$.

Pleito que la Congregación tiene para que el Dr. D. Francisco de Quintana entregue el censo de la manda que el Lic. Jerónimo de Quintana hizo a la Congregación y se hagan las diligencias nuevas hasta su entrega ${ }^{76}$.

Que el Dr. Francisco de Quintana entregue como testamentario de Jerónimo de Quintana a la Congregación el censo de los 1400 ducados de plata que el susodicho mandó a la Congregación que se pagaran ante Manuel López, notario propietario de la Audiencia arzobispal ${ }^{77}$.

Prosíganse las diligencias judiciales para que el Sr. Doctor Quintana entregue a la Congregación las escrituras del censo ${ }^{78}$.

El proceso, conforme a las fechas de las actas, se prolongó durante varios años, desde fines de 1644 hasta comienzos de 1649, con un dictamen a favor de la Congregación, la cual consiguió finalmente el pretendido censo.

Todas estas circunstancias, derivadas de las obligaciones contraídas como testamentario $^{79}$, resintieron la economía de Quintana. Como manifiesta Álvarez de Baena en Hijos ilustres, la misma Congregación le prestó ayuda en su pobreza y necesidades ${ }^{80}$. Una circunstancia, por otra parte, bastante paradójica. Es probable que a los gastos del pleito se sumaran también los suscitados por otra demanda: la obtención de una capellanía legada igualmente en su testamento por don Jerónimo $^{81}$ :

Declaro que, asimismo, yo tengo otra capellanía que fundaron los herederos de Gil de Quintana, deán que fue de Chiapa, mi tío, en cuya fundación se da facultad al capellán que fuere de ella para que pueda

${ }^{75}$ Ibíd., 6 de noviembre de 1645, fol. 230. Sebastián Muñiz es el comisario del pleito.

${ }^{76}$ Libro III de Acuerdos, 10 de diciembre de 1646, fol. 4v.

${ }^{77}$ Ibíd., 21 de enero de 1649, fol. 29v.

${ }^{78}$ Ibíd., al margen.

${ }^{79}$ L. Ballesteros Robles también ratifica esta situación: “fueron tantas las dificultades que se le presentaron para desempeñar este cargo [de testamentario], que gastó grandes sumas que le condujeron a la mayor pobreza, de suerte que la congregación tuvo que socorrerle" (1912), p. 530.

${ }^{80}$ J. A. Álvarez de Baena (1789-1790), II, p. 173.

81 Para J. de Entrambasaguas, los problemas económicos de Quintana derivan de la obtención de esta capellanía, no del pleito con la Hermandad (1967), p. 75. 
nombrar para después de sus días, al pariente más cercano; y yo conformándome con la dicha fundación, nombro por capellán de ella al doctor Francisco de Quintana, rector del hospital de la Latina, por ser pariente más cercano por línea de varón, para que haya y goce la renta de ella y la cobre y diga las misas de la dicha capellanía ${ }^{82}$.

Sin embargo, la carencia de referencias a este asunto en las actas y en otros documentos impide esbozar cualquier teoría al respecto: "Una capellanía que Jerónimo de Quintana hizo al Dr. Francisco de Quintana, su hermano"83. Lo más probable es que, como dejan de manifiesto los documentos consultados, las penurias económicas de la que hablan los biógrafos se deban a los pleitos entablados con la misma Comunidad y no a otras circunstancias.

\section{Actividad y vínculos literarios}

Todos estos acontecimientos no transcurren aisladamente, sino de manera paralela a la carrera literaria. La inmersión del joven escritor en el ámbito literario fue relativamente temprana. Su primera aparición pública, en calidad de poeta, tuvo lugar en las justas poéticas que se celebraron en la iglesia de San Andrés en Madrid en el año 1620 con motivo de la conmemoración en la ciudad de la beatificación de su patrón San Isidro. El jurado del certamen, en el que participaron numerosos poetas contemporáneos, estuvo presidido por Lope de Vega, quien reunió todas las composiciones del concurso ese mismo año y las publicó con el título de Justa poética y alabanzas justas que hizo la insigne villa de Madrid al bienaventurado san Isidro en las fiestas de su beatificación.

Quintana participa en este concurso poético con dos composiciones: cuatro décimas en el tercer certamen y una glosa burlesca en el noveno. Aunque son composiciones juveniles de mediana calidad, Lope de Vega elogia su contribución en los siguientes versos: "Sus galas Luis de Belmonte / con Fernando de la Serna, /

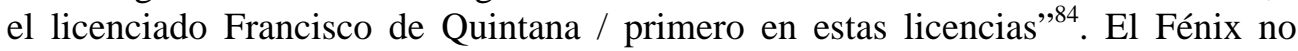
publica la lista de los galardonados en los diferentes certámenes de esta edición, por lo que se desconoce si Quintana obtuvo algún premio en alguna de las categorías participantes. Zimic, junto a Américo Castro y Hugo Rennert, lamenta este hecho, ya que la publicación de las listas permitiría apreciar "los cánones del gusto contemporáneo"; sin embargo, esta consideración resulta un tanto ingenua por motivos de sobra conocidos por la crítica ${ }^{85}$. Para el especialista esloveno esta

82 J. Matilla Tascón (1983), p. 199.

${ }^{83}$ Libro III de Acuerdos, 2 de octubre de 1647, fol. 13.

${ }^{84}$ A. de Sancha (1776), XI, p. 593.

85 No puede obviarse la conspicua falta de ecuanimidad del Fénix en los certámenes poéticos, su inmutable inclinación al amiguismo y la tendencia a la propia concesión de premios. 
participación de Quintana en el concurso poético representa el primer contacto del escritor con el mundo literario. Pero no puede olvidarse que el poeta novel, como otros jóvenes escritores de la época, compuso sus primeros versos en el seno de las tertulias literarias del momento y, más concretamente, en la Academia de Madrid de don Francisco de Medrano en la que participaban, entre otros, sus amigos Pérez de Montalbán y Lope de Vega ${ }^{86}$.

Dos años más tarde, en junio de 1622, vuelve a concurrir en otras dos justas celebradas en Madrid con motivo de la canonización de su patrón y otros cuatro santos: san Ignacio de Loyola, san Francisco Javier, santa Teresa de Jesús y san Felipe Neri ${ }^{87}$. La compañía de Jesús promovió uno de los concursos para celebrar la canonización de sus dos $\operatorname{santos}^{88}$ y la villa de Madrid, el segundo ${ }^{89}$. Quintana en esta ocasión concursó con varias composiciones en ambos certámenes. Al primero presentó un romance sobre el retiro y la rigurosa penitencia de San Ignacio de Loyola en Manresa, con el que quedó tercero en esa modalidad tras Calderón de la Barca y Antonio de Silva. El poema, que comienza con el verso "Inspire ardor soberano", resulta una composición pulcra en la forma y transida de cierto misticismo. Al segundo certamen concurrió en cuatro categorías - décimas, tercetos, glosa y soneto- y escribió también un soneto para los preliminares en alabanza del altar que mandó erigir su tío delante del hospital de la Latina. La calidad de los

${ }^{86}$ Tanto B. Ripoll como A. Cayuela aseveran la participación de Quintana en la Academia de Medrano. La primera cita entre los contertulios a León de Tapia, José de Valdivieso y María de Zayas. La segunda añade a Pérez de Montalbán, Salas Barbadillo, Gabriel del Corral y Gabriel Bocángel. También B. Chenot confirma la presencia de Quintana en la academia literaria al aparecer su nombre entre los participantes en el homenaje al mecenas. J. Sánchez, por su parte, incorpora a Quintana al catálogo académico a partir de la mención y el elogio del propio Medrano a los participantes en las reuniones literarias de su casa en Los favores de las musas (1961), p. 52.

${ }^{87}$ Sobre las fiestas de canonización de estos santos, véase J. Deleito y Piñuela (1963), pp. 138-141.

${ }^{88}$ Las fiestas del Colegio Imperial se solemnizaron el 18 de junio, aunque estaban programadas para la semana anterior. Monforte y Herrera publicó la relación de las fiestas ese mismo año con el título de Relación de las fiestas que ha hecho el colegio Imperial de la Compañía de Jesús de Madrid en la canonización de San Ignacio de Loyola y San Francisco Xavier. El volumen tras exponer los actos conmemorativos y la ornamentación de la ciudad, recoge todos los poemas de los competidores en el concurso. El marqués de Velada, el Príncipe de Esquilache y el marqués de Cerralbo formaron el jurado.

${ }^{89}$ La villa de Madrid fue la encargada de promover el segundo concurso, nuevamente presidido por Lope de Vega, aunque en esta ocasión no fue ni juez, ni secretario, ni fiscal, como señala J. de Entrambasaguas (1942), p. 219. Igual que en las justas de beatificación de San Isidro, el Fénix publicó la relación de las fiestas con el título de Relación de las fiestas que la insigne villa de Madrid hizo en la canonización de su bienaventurado hijo y patrón san Isidro..., en Colección de las obras sueltas, 1776, XII. 
poemas que presenta Quintana al certamen resulta más bien desigual. Las décimas del tercer combate "Cuando entre celajes rojos" carecen de sello propio debido al empleo de imágenes y recursos bastante comunes. En los tercetos del noveno combate entrelaza dos motivos cruciales en el Barroco: la exaltación de la monarquía y la devoción religiosa. La glosa del último combate, bastante parca en recursos estilísticos, constituye un homenaje a la villa de Madrid. El motivo es sencillo y la finalidad del poema, laudatoria. Gracias a la publicación de los ganadores se sabe que Quintana obtuvo el primer premio en la modalidad de sonetos, un galardón que no sorprende demasiado, ya que de una simple ojeada se aprecia la innegable filiación del poema con los versos de Lope ${ }^{90}$.

En estas justas se suman, a los poetas del certamen de 1620, otros escritores de primera fila como Guillén de Castro, Tirso de Molina, Calderón de la Barca, Salas Barbadillo o Castillo Solórzano. Con algunos de ellos coincidió Quintana por primera vez en la celebración de las justas, pero a otros ya los conocía de las tertulias literarias celebradas en la academia de Medrano desde 1617. En esta tertulia, conocida también como mantuana se inicia el joven escritor en la vida literaria, escribe sus primeros versos y se relaciona con los escritores más célebres del momento.

Habría que esperar solo varios años para que aparecieran sus dos únicas novelas, Experiencias de amor y fortuna (1626) y la Historia de Hipólito y Aminta (1627), ambas de estructura bizantina con interpolación de relatos cortesanos ${ }^{91}$. A pesar del éxito y reconocimiento de ambas novelas, Quintana no volvió a escribir ninguna historia de ficción, probablemente porque la novela, un género en ciernes, no gozaba de valoración y reconocimiento cultural en su época.

En este contexto poético donde reinan los éxitos y las polémicas literarias encontró Quintana a sus mejores amigos y valedores, como demuestran los elogios y las palabras de afecto de sus correligionarios. Una simpatía, que sin dejar de ser sincera, refleja por otra parte el pacto soterrado de respaldo y apoyo mutuos que sostuvieron los escritores áureos. Una simple ojeada a los preliminares de algunas obras de este período constata esta hipótesis. Sin ir más lejos, en Experiencias de amor y fortuna, aparte de la carta aval de Lope, concurren los poemas de tres reconocidos escritores: uno de Pérez de Montalbán, otro de León y Tapia y un tercer poema de María de Zayas. Las tres composiciones, aunque de diferente corte métrico, corresponden al género laudatorio. La amistad de Quintana con estos escritores remonta a los años de la tertulia madrileña de Medrano, aunque con León y Tapia debió de ser posterior y probablemente intermediada por Pérez de

${ }^{90} \mathrm{El}$ poema puede leerse en Colección de las obras sueltas (1776), XII, p. 252.

${ }^{91}$ Véase M. R. Lepe García (2013), pp. 261-352. 
Montalbán ${ }^{92}$. Estos patrocinios literarios no parecen, pues, en ningún caso gratuitos y circunstanciales. Pérez de Montalbán, por ejemplo, le devuelve a Quintana en este poema preliminar el beneficio por el encomio de su sabiduría y elocuencia en las décimas de Sucesos y prodigios de amor, unos versos escritos a su vez por Quintana en agradecimiento por la dedicatoria que le había ofrendado el hijo del librero en Los primos amantes.

La retribución de las prebendas literarias concedidas por otros miembros de la academia mantuana, tales como Alonso de Castillo Solórzano, José de Valdivieso o Juan de Piña, pueden rastrearse igualmente en las novelas de estos escritores. La amistad de Quintana con el primero de ellos debió de comenzar en torno a 1619 o $1620^{93}$. El ingreso de Castillo Solórzano en los círculos literarios de Madrid se produjo seguramente nada más llegar a la capital, ya que el único motivo que le mueve a asistir en la corte es el deseo de probar fortuna en el ámbito literario. El afecto entre los dos escritores se mantuvo vivo durante años, como rubrican una décima laudatoria de Quintana en los preliminares de Tiempo de regocijo y carnestolendas de Madrid (1627), novela que apareció poco antes que la Historia de Hipólito y Aminta ${ }^{94}$ y la posterior aprobación, años más tarde, de La Garduña de Sevilla (1642).

La relación de Quintana con Joseph de Valdivieso, figura destacada tanto en el ámbito eclesiástico por las distinciones de capellán del cardenal Sandoval y Rojas y el infante-cardenal don Fernando de Austria, como en el literario por las creaciones poéticas y dramáticas y su faceta de censor de libros ${ }^{95}$, debió de venir seguramente de la intermediación del maestro Lope de Vega. El aprecio de Valdivieso hacia Quintana queda patente en el soneto que compone para los preliminares de la Historia de Hipólito y Aminta en donde, con tono elevado y pretensión laudatoria, equipara al novelista con el mismo Heliodoro, del igual modo que Lope en su

\footnotetext{
${ }^{92}$ Montalbán le manifiesta su amistad en el canto IV del Orfeo en lengua castellana. En esta obra también elogia a Lope, Gabriel del Corral, Tirso de Molina, José de Valdivieso y al mismo Quintana.

${ }^{93}$ Un documento legal de don Juan de Ulloa sobre los derechos a la herencia de su madre, y otro literario, un soneto laudatorio preliminar en Vida y penitencia de santa Teodora de Alejandría de González de Torneo (1619), atestiguan la presencia del tordesillano en la corte por entonces.

${ }^{94}$ Esta información se colige del prólogo de J. Pérez de Montalbán en Tiempo de regocijo donde invita al lector amigo a la lectura de cinco libros que están "ya para darse a la imprenta” (1999), p. 1025.

95 Historia de Hipólito y Aminta (1627), preliminares, fol. 3v. Como censor de libros, Valdivieso aprobó numerosos textos literarios de gran calidad en nuestras letras, como la segunda parte de El Quijote y Los trabajos de Persiles y Sigismunda de Cervantes, las Rimas humanas y divinas de Lope de Vega, las Novelas amorosas y ejemplares de María de Zayas o la Agudeza y arte de ingenio de Baltasar Gracián.
} 
soneto preliminar. La ponderación de Valdivieso, encomiadora de las cualidades literarias del joven Quintana -ingenio, estudio, alteza, invención, suspensión, arte y pureza- resulta mayúscula; en ella interviene sin duda el afecto hacia el escritor amigo.

A la estima de los autores mencionados, habría que añadir el aprecio de Juan de Piña. El afecto del notario del rey hacia el futuro rector de la Latina queda patente en su novela Casos prodigiosos y cueva encantada (1628), donde el homenaje va más allá de lo meramente convencional al incluir al escritor como personaje en la ficción novelística. El narrador pondera el ingenio y la agudeza de Quintana durante su aparición en la trama en los siguientes términos:

Tenía don Juan en San Sebastián a don Francisco de Quintana, doctor en teología, principal caballero, facultad que habían estudiado colegiales en Salamanca. Decía la persona con el ingenio florido, agudo de los maravillosos de su tiempo [...] Es famoso poeta y ha pasado trabajos de la imprenta, si no válidos a excusar erratas casi inevitables en libros; que libros excelentes como su ingenio le han esparcido por el mundo con grande aprobación por haber puesto al florecer en razón su entendimiento ${ }^{96}$.

Más adelante, cuando don Juan, Ricardo y los criados dejan la ciudad de San Sebastián para viajar a Irún, el narrador vuelve a loar a Quintana en la despedida, mencionando en esta ocasión su producción novelística: "El doctor don Francisco de Quintana, famoso por sí, y sus Experiencias de amor y fortuna, Hipólito y Aminta, se quedó a dar fin a sus negocios" ${ }^{\prime 7}$.

Por todos los elogios y palabras de aprecio que afloran en los textos literarios de la época, resulta evidente que Quintana mantenía una relación bastante cordial con los escritores afines; sin embargo, es incuestionable que los vínculos afectivos más estrechos y sólidos los mantuvo con el Fénix de las letras y su amigo Pérez de Montalbán. El respaldo categórico de ambos fue decisivo para el reconocimiento novelístico de Quintana, acreditado por entonces en los ambientes literarios por una producción poética bastante limitada: las composiciones de las justas y dos décimas preliminares publicadas en Triunfos divinos de Lope de Vega y Tiempo de Regocijo de Castillo Solórzano. Las pruebas de afecto y admiración en el ámbito literario van en una y otra dirección. Tras los versos encomiásticos de Lope en las justas de 1620 y 1622, Quintana le brinda un poema preliminar a su amigo en Triunfos divinos en correspondencia por los versos que le regala el Fénix en la silva VII. Un año más tarde, Quintana le dedica a Lope su primera novela, Experiencias de amor y

${ }_{97}^{96}$ J. de Piña, Casos prodigiosos y cueva encantada (1907), p. 80.

${ }^{97}$ Ibíd., p. 90. 
fortuna, para expresar así su admiración y respeto al maestro. Lope, a su vez, agradece este homenaje con una carta prólogo henchida de erudición, donde pondera de manera reiterada los méritos de Quintana. Posteriormente, en los preliminares de la Historia de Hipólito y Aminta, aparece un soneto laudatorio del Fénix: "Este de Apolo singular tesoro", en el que Lope encumbra a su autor identificándolo con el mismo Heliodoro ${ }^{98}$. Y unos años más tarde, en las Rimas de Tomé de Burguillos, Lope le ofrenda a su discípulo el soneto De algunos predicadores naturales de Madrid: Al doctor Francisco de Quintana, en cuyos tercetos queda de manifiesto el fuerte apego hacia su amigo y discípulo.

Por su parte, las principales muestras literarias de estimación de Montalbán a Quintana se hallan en la dedicatoria de Los primos amantes (1624), que puede considerarse un breve tratado sobre la amistad; en el soneto preliminar de Experiencias de amor y fortuna (1626) "Engalana, matiza, alumbra y dora”, que vincula la ficción al referente griego por antonomasia ("Desde Grecia Teágenes dio aviso"); y en la aprobación de la Historia de Hipólito y Aminta un año más tarde (1627), donde manifiesta nuevamente la admiración y estima hacia su creador ${ }^{99}$. Por su parte, Quintana corresponde a esta protección con unas décimas preliminares en los Sucesos y prodigios de amor (1624) y, de manera póstuma, con el prólogo al Segundo tomo de las comedias publicado por su padre, aparte de la oración fúnebre para la predicación de sus exequias.

La amistad de este triángulo literario se mantendrá viva hasta el fallecimiento del Fénix el 27 de agosto de 1635. Montalbán seguirá al maestro solo tres años más tarde, en 1638. A Quintana, como amigo más allegado, le corresponderá la predicación de las honras fúnebres de ambos. La presencia del autor en el lecho de muerte del Fénix, como recuerda Pérez de Montalbán; su designación como albacea de Lope en el primer testamento fechado en 1627; y la donación por parte de este de un par de cuadros según los documentos vienen a corroborar la íntima amistad que mantuvieron los dos escritores durante largos años. Tras su muerte, el intenso vínculo afectivo de Montalbán hacia su mentor desde la infancia quedaría plasmado en la primera biografía oficial del Fénix, aparecida solo un año después del deceso con el título de Fama póstuma a la vida muerte del doctor frey Félix Lope de Vega

\footnotetext{
${ }^{98}$ Lope lo llama "Fénix de la pluma de Heliodoro". En estos años Quintana ocupa el cargo de capellán en la casa de don Diego Ramírez de Haro, descendiente de Beatriz Galindo. A este noble vinculado al hospital de la Latina le dedica la Historia de Hipólito y Aminta. El dato procede de la firma de la dedicatoria: “De vuestra merced, capellán” (1627), preliminares, fol. 6.

${ }^{99}$ F. de Quintana (1627), aprobación de Juan Pérez de Montalbán, preliminares, fol. 2v. A esta novela ya le había dedicado Montalbán unas palabras en los preliminares de Tiempo de regocijo.
} 
Carpio. En ella Montalbán celebra, en un tono verdaderamente encomiador, la predicación fúnebre de Quintana, que se celebró en san Miguel de los Octoes ${ }^{100}$.

Tres años más tarde, el 25 de junio de 1638, fallece el hijo del librero con solo 36 años de edad tras sufrir durante año y medio un padecimiento cerebral no especificado ${ }^{101}$. Quintana también escribió para él, igual que para Lope, un sermón titulado Oración panegírica o sermón fúnebre. Honores extremos del Doctor Juan Pérez de Montalbán, que se publicó un año después, en junio de 1639 en Lágrimas panegíricas a la temprana muerte del gran poeta i teólogo insigne Doctor Juan Pérez de Montalbán ${ }^{102}$. El mismo año de la defunción, Quintana prologa la edición del Segundo tomo de las comedias escogidas, publicado póstumamente por su padre el impresor Alonso Pérez.

\section{Una última etapa}

En el decenio 1630-1640, la vida de Quintana se orienta cada vez más al ejercicio sacerdotal. Pocos datos constatables permiten forjar con precisión su trayectoria biográfica en estos años, a excepción de la información que procede de los escritos y las actas de la Congregación. Tras la publicación de las dos ficciones novelísticas, Quintana se aleja de la literatura, aunque no abandona completamente la escritura. Sus intereses intelectuales en estos momentos se encauzan hacia otros ámbitos. A tenor de lo que nos cuenta Pérez de Montalbán en el Para todos, a comienzos de la tercera década del seiscientos Quintana se halla en la redacción de dos obras: Epítome de una historia de España y República imaginada, "trabajos todos de gran peso, como puede seguramente creerse de su mucha erudición y continuos estudios” ${ }^{\prime 03}$. El paradero de estos libros sigue siendo una incógnita en la actualidad, ya que como indica Beatriz Chenot "on n'en trouve aucune trace dans les catalogues bibliographiques" ${ }^{\text {104 }}$. Hoy por hoy no es posible saber si Quintana terminó de escribir estas obras o si fueron estampadas en la imprenta. Por los títulos y el comentario de Montalbán debieron de ser tratados de contenido histórico y político dotados de gran erudición ${ }^{105}$.

${ }^{100}$ El sermón está fechado el siete de septiembre de 1635. Fama póstuma, en Colección de las obras sueltas (1776), XX, p. 44.

${ }^{101}$ Me remito a la información que aporta Quintana en el prólogo al segundo tomo de las Comedias de Juan Pérez de Montalbán (1638), puesto que la duración de la enfermedad varía de unos biógrafos a otros. A. Cayuela habla de un período de tres años (2005), p. 63; mientras C. A. de la Barrera Leirado reduce la enfermedad a seis meses (1860), p. 266.

${ }^{102}$ Los textos son publicados por el padre del difunto, el librero Alonso Pérez.

103 J. Pérez de Montalbán (1999), p. 859.

${ }^{104}$ B. Chenot (1982), p. 132.

${ }^{105}$ El primero pudo ser una historia abreviada de España, siguiendo la veta cronística de su tío don Jerónimo de Quintana; y el segundo, un estudio ensayístico de contenido políticosocial y/o religioso en la línea de la República de Platón, La ciudad de Dios de San Agustín 
Aparte de estas dos obras, recuperando la inspiración poética de su etapa juvenil, Quintana compone un romance religioso "Apresurado el aliento" para la compilación poética titulada Avisos para la muerte ${ }^{106}$. Formado por cuarenta coplas arromanzadas, el poema se distingue por el contenido devocional y el tono íntimo. El motivo poético es el diálogo del creyente con Cristo en los instantes previos a la muerte.

Poco después, escribe las honras fúnebres de Lope y Montalbán, como ya se ha indicado más arriba, y el prólogo a las comedias del segundo. En este período presenta un romance a un certamen celebrado en el Retiro de Madrid en presencia del rey ${ }^{107}$. Sin embargo, es necesario especificar que en esta ocasión no participó en el concurso con una composición original, sino que salvó el compromiso con un poema amoroso de la Historia de Hipólito y Aminta, concretamente "Viendo que Lisi desprecia”, que se haya inserto en el discurso tercero.

En el decenio siguiente, el reconocimiento de Quintana como escritor, teólogo y predicador es general y absoluto. Sus últimas inmersiones en el mundo literario consisten en la aprobación de La garduña de Sevilla (1642) de Castillo Solórzano y el sermón Del premio eterno de los justos en la gloria, publicado en 1645 en una colección de sermones varios ${ }^{108}$. Por las referencias del subtítulo, el discurso es la reproducción escrita de una homilía predicada por Quintana un sexto domingo de cuaresma en la iglesia parroquial de San Pedro de Madrid. La materia de la oración, que consta de tres cuerpos bien delimitados, es teológica y trata sobre las invocaciones del Padrenuestro.

Su actividad, no obstante, sigue siendo muy intensa en el ámbito religiosoeclesiástico, tanto por las nuevas responsabilidades en el rectorado del hospital de la Latina, como por las distintas funciones ejercidas en la Congregación de San Pedro. En este período es reelegido capellán mayor en 1643 y 1649. Y, excepcionalmente, ejerció esta distinción una vez más en ausencia del superior de la Comunidad en una junta celebrada en noviembre de $1646^{109}$. Asimismo, la Hermandad se mostró deferente con Quintana un mes antes de esta fecha, en octubre, al formar parte de la delegación encargada de recibir en la Congregación al cardenal arzobispo de Toledo. En esta década y la siguiente, hasta su muerte, el novelista entrega su vida al sacerdocio, a la dirección del hospital de la Latina, al ejercicio de sus tareas en la

o la Utopía de Tomás Moro. La pérdida o la no impresión de estos volúmenes impiden cualquier valoración textual.

${ }^{106}$ L. Remírez de Arellano (1634), fols. 31v-35v. El volumen es un poemario constituido por un conjunto de treinta poemas escritos por autores de primera fila de la época, tales como Lope de Vega, Calderón, Mira de Amescua o Joseph de Valdivieso.

${ }^{107}$ Ms. 3773 de la Biblioteca Nacional de Madrid. En el certamen que se hizo en presencia de su majestad en el Retiro, 1638.

108 Recopilada en 1645 por el doctor don Francisco Ignacio de Porres.

${ }^{109}$ Libro III de Acuerdos, 26 de octubre de 1646, fol. 4v. 
Compañía -cada vez más reducidas y espaciadas en el tiempo- y al cuidado de los enfermos del hospital.

También, en relación con la vida religiosa, el novelista ingresó en la Orden Tercera de San Francisco el 15 de septiembre de $1641^{110}$, donde desempeñó funciones diversas. Según Entrambasaguas, fue vocal de su junta, enfermero mayor en 1644 y coadjutor de ministro en $1647^{111}$. Zimic, siguiendo supuestamente a Bartolomé José Gallardo, apunta a que Quintana fundó también en 1643 una capellanía en la parroquia de San Martín en Madrid, pero el dato no aparece en la obra del bibliógrafo citado ${ }^{12}$, por lo que es probable que se trate de un error de referencia.

De los últimos años de su vida, la década de los cincuenta, no existe prácticamente ninguna información. El único dato constatable es la fecha de su fallecimiento, que se produjo el 25 de enero de $1658^{113}$, tal como atestiguan los libros de actas de la Hermandad. El entierro tuvo lugar en el convento de San Francisco el Grande, entonces panteón de los hombres ilustres ${ }^{114}$. La Congregación de Sacerdotes se encargó de costear las honras fúnebres en la parroquia de San Pedro el Real, en la actualidad conocida como San Pedro el Viejo ${ }^{115}$. Sobre el paradero de sus restos mortales tras la reconstrucción del convento franciscano, no existe noticia alguna.

Básicamente esta es la biografía que hasta la actualidad se puede trazar de Francisco de Quintana. En este artículo se aportan, pues, nuevos datos completamente inéditos sobre la vida del autor madrileño, tales como las fechas de nacimiento, bautismo y ordenación sacerdotal; la trayectoria académica en la Universidad de Alcalá, el curso de la carrera eclesiástica y las tareas desempeñadas en la Congregación de San Pedro desde su ingreso en 1625; y algunas noticias sobre los pleitos judiciales derivados del testamento de su tío don Jerónimo de Quintana. De igual manera, se liman algunas de las aportaciones de la crítica anterior en aras de la veracidad. No obstante, quedan aún por desvelar bastantes incógnitas sobre la vida y carrera literaria de este escritor. Es probable que nuevas incursiones en los archivos permitan resolver esos silencios e interrogantes y que en un futuro cercano pueda completarse este bosquejo biográfico.

\footnotetext{
${ }^{110}$ A esta congregación habían pertenecido también los padres de Quintana y Lope de Vega.

111 J. de Entrambasaguas (1967), p. 75.

112 S. Zimic (1975), p. 188, nota 61. Habría que pensar si no se trata de una confusión. B. J. Gallardo no recoge nada al respecto en el tomo II de su obra (1866), p. 133.

${ }^{113}$ Aunque J. de Entrambasaguas adelanta la fecha al 24 de enero (1967), p. 78.

${ }^{114}$ Sobre la historia de este templo basilical, véase P. Esteban Ibáñez (2005).

${ }^{115}$ Esta información procede de J. de Entrambasaguas (1967), p. 78.
} 


\section{Obras citadas}

\section{Obras citadas de Francisco de Quintana}

QUINTANA, Francisco de: Avisos para la muerte, recogidos y publicados por don Luis Remírez de Arellano, Madrid, por la viuda de Alonso Martín, a costa de Alonso Pérez, 1634.

: Colección de las obras sueltas assí en prosa como en verso / de D. Frey Lope Félix de Vega Carpio, Madrid, Imprenta de Antonio Sancha, 1776, tomo I-XXI.

: En las Honras de Lope Félix de Vega Carpio Sermón fúnebre, Madrid, Imprenta del Reino, 1635.

: Escuela de discursos formada de sermones varios escritos por diferentes autores maestros grandes de la predicación... Alcalá, en la imprenta de María Fernández, a costa de Juan Antonio Bonet, 1645.

: Experiencias de amor y fortuna, ed. Andrea Bresadola, Sevilla, UNIA, 2012.

: Experiencias de amor y fortuna, Madrid, por la viuda de Alonso Martín, 1626.

: Historia de Hipólito y Aminta, Madrid, por la viuda de Luis Sánchez, 1627.

: Justa poética y alabanzas justas que hizo la insigne villa de Madrid al bienaventurado San Isidro en las Fiestas de su Beatificación, recopiladas por Lope de Vega Carpio, Madrid, Viuda de Alonso Martín, 1620.

: Lágrimas panegíricas a la temprana muerte del gran poeta y teólogo insigne doctor Juan Pérez de Montalbán, a cargo de Pedro Grande de Tena, Madrid, Imprenta del Reino, 1639.

: Oración panegírica o sermón fúnebre: honores extremos del doctor Juan Pérez de Montalbán, 1639?

: Relación de las fiestas que la insigne villa de Madrid hizo en la canonización de su bienaventurado hijo y patrón San Isidro...,/ por Lope de Vega Carpio, Madrid, viuda de Alonso Martín, 1622.

: Relación de las fiestas que ha hecho el colegio imperial de la Compañía de Jesús de Madrid en la canonización de San Ignacio de Loyola y San Francisco Xavier/ por Don Fernando Monforte y Herrera, Madrid, por Luis Sánchez, 1622.

\section{Fuentes primarias}

CASTILlo SOlÓRZANO, Alonso: Tiempo de regocijo y carnestolendas de Madrid, Madrid, Luis Sánchez, 1627.

: La garduña de Sevilla y anzuelo de las bolsas, Madrid, Imprenta del Reino, 1642. 
CueVA, Francisco de la, Mojiganga del gusto en seis novelas y Jacinto de Ayala, Sarao de Aranjuez, ed. David González Ramírez, Zaragoza, Larumbe, 2010.

Libro de elecciones de oficiales y acuerdos de la Congregación, de 25 de junio de 1619 a 11 de agosto de 1625.

Libro II de Acuerdos de la Venerable Congregación de San Pedro, 22 de agosto de 1624 a 3 de mayo de 1646.

Libro III de Acuerdos de la Venerable Congregación de San Pedro, 2 de julio de 1646 a 17 de abril de 1662.

Libros de matrículas de la Universidad de Alcalá, Archivo Histórico Nacional, Números 444-445.

LOPE DE VEGA: Triunfos divinos con otras rimas sacras, Madrid, viuda de Alonso Martín, a costa de Alonso Pérez, 1625.

: Laurel de Apolo con otras rimas, en Obras completas de Lope de Vega, Madrid, Fundación José Antonio de Castro, 2003, vol. V. : Rimas humanas y divinas del licenciado Tomé de Burguillos, ed. Juan Manuel Rozas y Jesús Cañas Murillo, Madrid, Castalia, 2005.

Manuscritos del Archivo eclesiástico de Toledo, 1620-1625.

Novelas cortas del siglo XVII, ed. Rafael Bonilla Cerezo, Madrid, Cátedra, 2010.

PÉREZ De MonTAlBán, Juan: Obra no dramática / Juan Pérez de Montalbán, ed. y pról. José Enrique Laplana Gil, Madrid, Fundación José Antonio de Castro, 1999.

: Fama póstuma, en Colección de las obras sueltas assí en prosa como en verso / de D. Frey Lope Félix de Vega Carpio, Madrid, Imprenta de Antonio Sancha, 1776, tomo XX.

: Segundo tomo de las Comedias del doctor Juan Pérez de Montalbán, Madrid, Imprenta del Reino, 1638.

: Sucesos y prodigios de amor en ocho novelas ejemplares, Tortosa, por Francisco Martorell, 1635.

: Fama póstuma a la vida y muerte del doctor frey Lope Félix de Vega Carpio y elogios panegíricos a la inmortalidad de su nombre, edición crítica, estudio y notas de Enrico Di Pastena, Pisa, ETS, 2001.

PIÑA, Juan de: Casos prodigiosos y cueva encantada, Madrid, Cotarelo y Mori, 1907.

\section{Fuentes secundarias: crítica}

Álvarez DE BAena, Joseph Antonio: Hijos de Madrid, ilustres en santidad, dignidades, armas, ciencias y artes, Madrid, Oficina de Benito Cano, 17891790, 2 vols.

ANTONIO, Nicolás: Bibliotheca Hispana Nova, Madrid, Visor, 1996.

Archivo biográfico de España, Portugal e Iberoamérica, ABEPI, ed. Víctor Herrero Mediavilla, München, K. G. Saur, I, 1986. 
BALLESTEROS RoBles, Luis: Diccionario biográfico matritense, Madrid, 1912.

BARrera LeIRAdo, Cayetano: Catálogo biográfico y bibliográfico del teatro antiguo español, Madrid, Rivadeneyra, 1860.

BOURLAND, Carolina: The short story in the seventeenth century. With a bibliography of the novella from 1576 to 1700, reimpresión Nueva York, Buró Franklin, 1973.

BRESADOLA, Andrea: "En las honras de Lope Félix de Vega y honores extremos del doctor Juan Pérez de Montalbán: Francisco de Quintana y la oratoria fúnebre del siglo XVII”, Lectura y signo, 7 (2012), pp. 67-89.

Cayuela, Anne: Alonso Pérez de Montalbán: un librero en el Madrid de los Austrias, Madrid, Calambur, Editorial, 2005, p. 153.

: Le Paratexte au Siècle d'Or, prosa romanesque, livres et lecteurs en Espagne au XVIIe siècle, Ginebra, Droz, 1996.

CHENOT, Beatriz: "Vie madrilène et roman byzantin dans l'oeuvre de Francisco de Quintana”, en M. Chevalier, Traditions populaires et difusión de la culture en Espagne (XVI-XVII siècles), Burdeos, Presses Universitaires, 1982, pp. 131-148.

COLÓN CALDERÓN, Isabel: "Los Engaños de mujeres de Miguel de Montreal”, Diálogos hispánicos de Ámsterdam, Ámsterdam, Rodopi, 8 (1989), pp. 111-124.

CRUZ CASADO, Antonio: Los amantes peregrinos Angelia y Lucenrique: un libro de aventuras peregrinas inédito, Madrid, Universidad Complutense, 1989.

: "Secuelas del Persiles", AIH, Actas XII, 1995, pp. 147-156.

DELEITO Y PIÑUelA, José: La vida religiosa española bajo el cuarto Felipe, Madrid, Espasa-Calpe, 1963.

ENTRAMBASAguAS, Joaquín de: Vida de Lope de Vega, Barcelona, Labor, 1942.

: "Una guerra literaria del Siglo de Oro", en Estudios sobre Lope de Vega, Madrid, CSIC, 1967, vol. 2, p. 75 y ss.

FERRERAS TASCÓN, Juan Ignacio: La novela en España. Historia, estudios y ensayos, Madrid, Laberinto, 2009, tomo II.

FORMICHI, Giovanna: "Saggio sulla bibliografia critica della novella espagnola seicentesca", en Lavori Ispanistici, 31973.

GALLARDO, Bartolomé José: Ensayo de una biblioteca de libros raros y curiosos, Madrid, Rivadenyra, 1866, (facsímil, Madrid, Gredos, 1968).

García GuAL, Carlos: "Menéndez Pelayo y sus estudios sobre las novelas griegas y latinas, antes y en sus orígenes de la novela”, en Raquel Gutiérrez Sebatián y Borja Rodríguez Gutiérrez (dirs.), Orígenes de la novela. Estudios, Santander, Servicio de Publicaciones de la Universidad de Cantabria, 2007.

GONZÁLEZ DE AMEZÚA, Agustín: "Formación y elementos de la novela cortesana”, en Discurso de recepción pública en la Real Academia Española, Madrid, 
Tip. de Archivos, 1929, reimpreso en Opúsculos histórico literarios, Madrid, CSIC, 1951, vol. I, pp. 194-279.

GonZÁlez MAS, Ezequiel: Historia de la literatura española, Puerto Rico, Editorial de la Universidad de Puerto Rico, 1989, vol. 3.

GonzÁlez Olmedo, Félix: “¿Qué dijeron de Lope los predicadores de sus honras?”, Razón y Fe, CVIII (1935), pp. 406-418.

GONZÁLEZ RoviRA, Javier: La novela bizantina de la Edad de Oro, Madrid, Gredos, 1996.

IBÁÑEZ, Esteban: San Francisco el Grande en la historia y en el arte, Madrid, Edicel, 2005.

INFANTES, Víctor: Del libro áureo, Madrid, Biblioteca Litterae Calambur, 2006.

LEPE GARCíA, Ma Rocío: Historia de Hipólito y Aminta de Francisco de Quintana: estudio y edición crítica, director Valentín Núñez Rivera, Universidad de Huelva, 2013.

: "La historia de Hipólito y Aminta de Francisco de Quintana: fuentes y modelos genéricos”, Etiópicas, 9 (2013), pp. 261-352.

LOZANO-RENIEBLAS, Isabel: "Los relatos orales del Persiles", Bulletin of the Cervantes Society of América, 22 (2002), pp. 111-126.

MATILla TASCÓN, Antonio: Testamentos de 43 personajes del Madrid de los Austrias, Madrid, Instituto de Estudios Madrileños, 1983.

RIPOLL, Begoña: La novela barroca. Catálogo bio-bibliográfico (1620-1700), Salamanca, Ediciones Universidad de Salamanca, 1991.

RuIz PÉREZ, Pedro: El siglo del arte nuevo (1598-1691), en José-Carlos Mainer (dir.), Historia de la literatura española, Barcelona, Crítica, 2010, vol. 3.

SÁNCHEZ, José: Academias literarias del Siglo de Oro español, Madrid, Gredos, 1961.

TEIJEIRO FUENTES, Miguel Ángel: La novela bizantina española. Apuntes para una revisión del género, Cáceres, Universidad de Extremadura, Servicio de Publicaciones, 1988.

y Javier GUIJARRO CEBALlOS: De los caballeros andantes a los peregrinos enamorados, Madrid, Eneida; Cáceres, Universidad de Extremadura, 2007.

VAL, Joaquín del: "La novela española del siglo XVII”, en Guillermo Díaz-Plaja (dir.), Historia general de las Literaturas Hispánicas, Barcelona, Barna, 1953, vol. 3.

ZIMIC, Stalisnav: "Francisco de Quintana, un novelista olvidado, amigo de Lope de Vega”, Boletín de la Biblioteca Menéndez Pelayo, 51 (1975), pp. 169-229. 